ESRI

SURVEY AND

STATISTICAL

REPORT SERIES

NUMBER 78

September 2019

\section{CONSTRUCTION OF THE ENERGY SOCIAL ACCOUNTING MATRIX FOR IRELAND}

KELLY DE BRUIN AND AYKUT MERT YAKUT

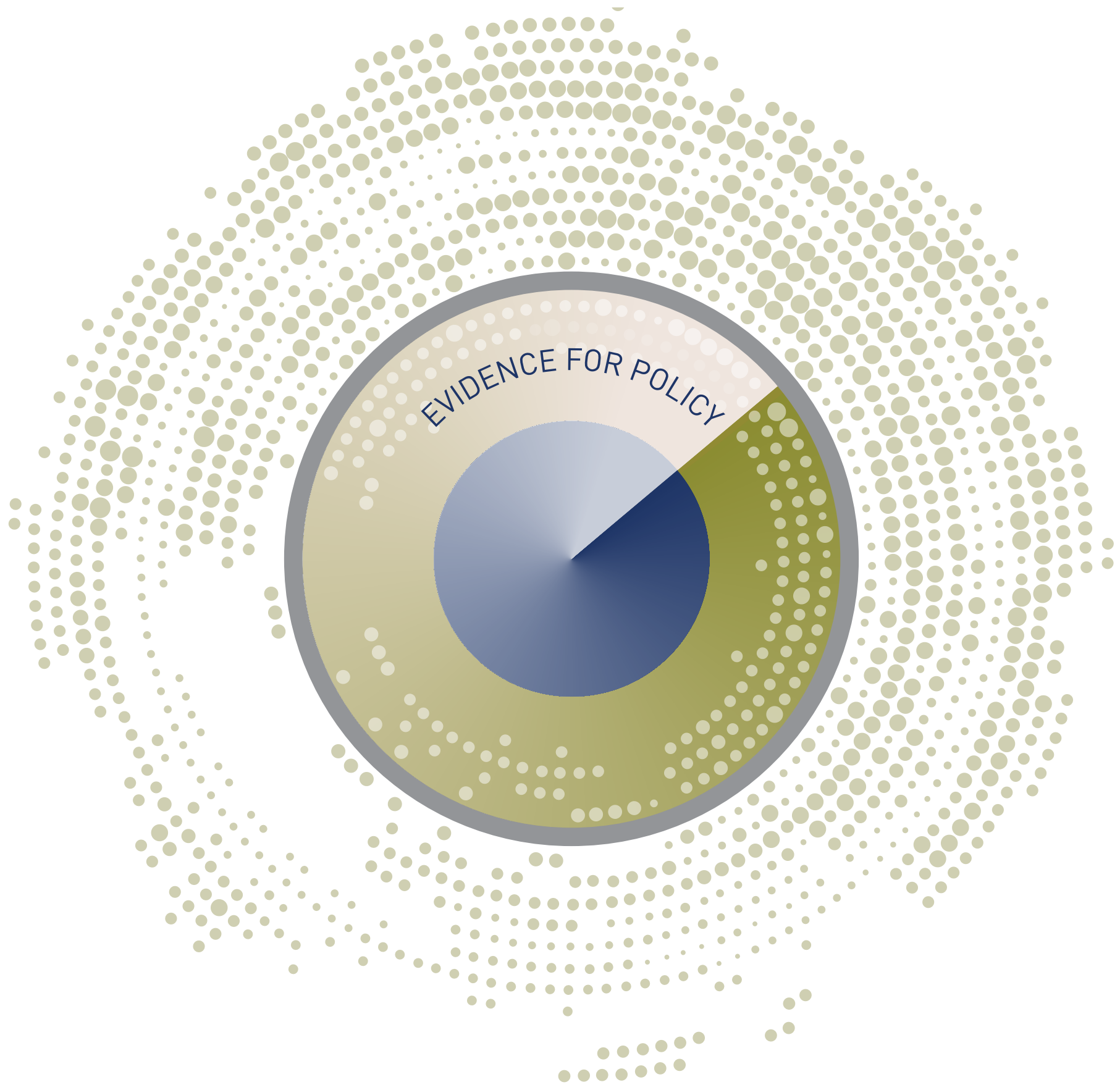




\section{Construction of the Energy Social Accounting Matrix for Ireland Published Version 1}

Kelly de Bruin

Aykut Mert Yakut

September 2019

\section{ESRI SURVEY AND STATISTICAL REPORT SERIES NUMBER 78}

Available to download from www.esri.ie

() The Economic and Social Research Institute

Whitaker Square, Sir John Rogerson's Quay, Dublin 2

ISBN 978-0-7070-0503-4

DOI https://doi.org/10.26504/sustat78

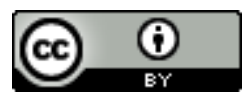

This Open Access work is licensed under a Creative Commons Attribution 4.0 International License (https:// creativecommons.org/licenses/by/4.0/), which permits unrestricted use, distribution, and reproduction in any medium, provided the original work is properly credited. 


\section{ABOUT THE ESRI}

The mission of the Economic and Social Research Institute is to advance evidence-based policymaking that supports economic sustainability and social progress in Ireland. ESRI researchers apply the highest standards of academic excellence to challenges facing policymakers, focusing on 12 areas of critical importance to 21 st Century Ireland.

The Institute was founded in 1960 by a group of senior civil servants led by Dr T. K. Whitaker, who identified the need for independent and in-depth research analysis to provide a robust evidence base for policymaking in Ireland.

Since then, the Institute has remained committed to independent research and its work is free of any expressed ideology or political position. The Institute publishes all research reaching the appropriate academic standard, irrespective of its findings or who funds the research.

The quality of its research output is guaranteed by a rigorous peer review process. ESRI researchers are experts in their fields and are committed to producing work that meets the highest academic standards and practices.

The work of the Institute is disseminated widely in books, journal articles and reports. ESRI publications are available to download, free of charge, from its website. Additionally, ESRI staff communicate research findings at regular conferences and seminars.

The ESRI is a company limited by guarantee, answerable to its members and governed by a Council, comprising 14 members who represent a cross-section of ESRI members from academia, civil services, state agencies, businesses and civil society. The Institute receives an annual grant-in-aid from the Department of Public Expenditure and Reform to support the scientific and public interest elements of the Institute's activities; the grant accounted for an average of 30 per cent of the Institute's income over the lifetime of the last Research Strategy. The remaining funding comes from research programmes supported by government departments and agencies, public bodies and competitive research programmes.

Further information is available at www.esri.ie 


\section{THE AUTHORS}

Kelly de Bruin is a Research Officer at the Economic and Social Research Institute (ESRI). Aykut Mert Yakut is a Postdoctoral Research Fellow at the ESRI.

\section{ACKNOWLEDGEMENTS}

The research carried out in this report was funded by the Department of Communications, Climate Action and Environment (DCCAE) and is part of an ongoing modelling project.

This report has been accepted for publication by the Institute, which does not itself take institutional policy positions. The report has been peer reviewed prior to publication. The authors are solely responsible for the content and the views expressed. 


\section{ACRONYMS}

$\begin{array}{ll}\text { ATS } & \text { Air transportation sector } \\ \text { BEUS } & \text { Business Energy Use Survey } \\ \text { CSO } & \text { Central Statistics Office } \\ \text { CT } & \text { Carbon tax } \\ \text { DT } & \text { Direct tax } \\ \text { EB } & \text { Energy balance } \\ \text { EGS } & \text { Electricity and gas supply sector } \\ \text { EU ETS } & \text { European Union Emissions Trading System } \\ \text { FISIM } & \text { Financial intermediation services indirectly measured } \\ \text { HBS } & \text { Household Budget Survey } \\ \text { HH } & \text { Households } \\ \text { HSL } & \text { High-skilled labour } \\ \text { LFS } & \text { Labour Force Survey } \\ \text { LSL } & \text { Low-skilled labour } \\ \text { MQE } & \text { Mining, quarrying, and extraction } \\ \text { MSL } & \text { Medium-skilled labour } \\ \text { NACE } & \text { Nomenclature of economic activities } \\ \text { ONM } & \text { Non-metallic mineral sector } \\ \text { PFOM } & \text { Petroleum, furniture and other manufacturing (PFOM) } \\ \text { PRT } & \text { Production tax } \\ \text { QAIS } & \text { Quarterly Accounts of Institutional Sectors } \\ \text { RHG } & \text { Representative household groups } \\ \text { RoW } & \text { Rest of the world account } \\ \text { SAM } & \text { Social accounting matrix } \\ \text { SEAI } & \text { Sustainable Energy Authority of Ireland } \\ \text { S-I } & \text { Saving-investment } \\ \text { SILC } & \text { Survey on Income and Living Conditions } \\ \text { ST } & \text { Sales tax } \\ \text { SUT } & \text { Supply and use table } \\ & \end{array}$




\section{EXECUTIVE SUMMARY}

A Social Accounting Matrix (SAM) represents the basis of a computable general equilibrium (CGE) model in terms of data. The matrix presents a snapshot of the economy for a given period of time, usually one year. This paper provides details concerning the data collection process to construct a SAM for the Ireland Environment, Energy and Economy (I3E) model. Due to the energy focus of the I3E model, the SAM is extended to construct an Energy SAM (ESAM). The ESAM includes several energy sectors and commodities and their concomitant carbon emissions. To this end, several data sources are used to disaggregate already available sectors and commodities into subsectors. 


\section{Introduction}

A computable general equilibrium (CGE) model reproduces the structure of the economy in its entirety including productive sectors, goods, households, factor inputs, trade and the government, where the nature of all existing economic transactions among diverse economic agents is quantified. To calibrate the CGE model parameters, a Social Accounting Matrix (SAM) is needed. A SAM can be defined as an organised matrix representation of all transactions and transfers between different production activities (sectors), goods (commodities), factors of production (labour, capital, and land), and institutions (households, corporate sector, government, and enterprises) within an economy and with respect to the rest of the world. A SAM is thus a comprehensive accounting framework within which the full circular flow of an economy (where households use their disposable income for consumption, which creates income for production, which creates income for factors of production which are owned by households, which creates income for households who again devote their income to consumption) is captured.

This paper explains the data collection process and balancing procedure of the ESAM as used in the I3E model in detail. The next section explains the basic structure of a typical SAM. Section 3 summarises the data sources utilised to construct firstly the SAM and then the ESAM for the Irish economy. Section 4 is devoted to explaining both the construction steps of the aggregated version of the Irish SAM and the relationships across the economic agents, as defined in the I3E model. Sections 5 summarises the disaggregation of the energy sectors and commodities and the construction process of the ESAM, whereas Section 6 explains the disaggregation of the household sector into different household groups. Appendix A explains the relations between different prices and valuations used in the input-output tables. Appendix $\mathrm{B}$ provides the lists of activities and commodities defined in the I3E model and finally, the mapping of the Household Budget Survey (HBS) consumption items to the I3E commodities can be found in Appendix C.

\section{Basic SAM Structure}

A typical SAM depicts all the transactions in the economy in the form of a symmetric matrix. Each economic agent is represented as both a row and a column account. The number of agents represented depends on the nature of the analysis. If a researcher wishes to explore the distributive effects of a policy change, there would be more than one households group. Each row of the SAM gives receipts of an account while the column gives the expenditure. An entry in row $i$ and column $j$ represents the receipts of account $i$ from account $j$. The total of each row has to be equal to the total of the corresponding column. The logic behind this rule is simple: an expenditure of one agent is the income of another agent, and an agent's income should be equal to its expenditure.

As a SAM is formed to calibrate the model parameters, the structure of a SAM is determined by the structure of the CGE model regarding the number of agents and commodities represented in the model. As summarised by Pyatt (1988), a SAM brings together data from many various sources to describe 
the structural characteristics and is a very good way of displaying information concerning the structural interdependence in an economy at both the macro and meso levels. Round (2003) describes the SAM as a meso-level framework, noting that it operates as a functional bridge between a macro framework and markets and institutions that have a more detailed description.

\section{Data Sources}

Generally, Input-Output (IO) tables are used to construct SAMs and are constructed based on the Supply and Use Tables (SUTs). The SUTs provide the most detailed data on the sources of supply and demand of commodities, including exports and imports, the cost of production, the composition of gross value added and taxes and subsidies on products. Industries are on the rows of SUTs while products are on the columns. The supply table provides information on which sectors produce which commodities, imports by commodities, trade margins, taxes, and subsidies on products. The use table, by contrast, is formed by using four different tables: domestic use table (usage of domestically produced products), import use table (usage of imported products), net tax table (tax minus subsidies) on products, and lastly trade margins table. Trade and transportation services measured by trade and transportation margins which are necessary to deliver commodities from factories and docks to markets. They are one of the basic components of the valuation process. ${ }^{1}$

Each national statistical office produces an IO table by applying either the product technology or the industry technology assumption to the SUTs. ${ }^{2}$ Regardless of the choice of conversion, the resulting IO will assume that each industry is associated with the production of a single product. In other words, IO tables restrict the information provided by SUTs, and do not allow industries to produce multiple products and do not allow commodities to be produced by multiple activities. However, secondary and tertiary products may play an essential role in some industries and should, therefore, be included. The latter restriction leads to ignorance concerning differentiated products produced by domestic industries.

In order to avoid the restrictions introduced by IO tables, a SAM can be constructed by directly using the SUTs. In this case, the domestic production can be represented more accurately, although several complexities emerge such that each industry has to determine the level of production of each product.

As a SAM records incomes and expenditures, which are flow variables, it provides a snapshot of the economy for a period of time. Choosing a year for which a SAM is constructed, the base-year, in other words, has important implications. By definition, a SAM depicts the economy in an accounting equilibrium where total expenditure is equal to total income for each agent. However, economic equilibrium requires that each agent does not tend to and has no incentive to change her/his behaviour. In other words, the decisions of agents are stable, which, in turn, requires stability of prices including commodity prices and factors of production prices since the latter determines income (cost of production) of house-

1 A brief explanation is provided on Appendix A. For further details, an interested reader is advised to see UN (1999); EUROSTAT $(2008,2013)$.

2 Details of these assumptions are beyond the focus of this document. Details can be found in the manuals mentioned above. 
holds (firms) and the former determines the consumption profiles of the agents. Therefore, selecting an appropriate base-year requires choosing a year in which prices are relatively stable.

Another essential restriction in choosing the base year is the availability of all required data, where the latest available data would be preferred. The latest SUTs for the Irish economy are available for the year 2015 in which there is a significant increase (of 26\%) in the gross domestic product due to relocated balance sheets in the reporting procedure, which are mainly dominated by intellectual property products (CSO, 2017). Since this updated process has no impacts on prices, disposable income, consumption or energy demand, the year 2014 is chosen as the base year as the relation between all economic variables were more consistent to each other in 2014.

As the data provided by the SUTs is not sufficient to construct a SAM, additional data at a macroeconomic level, including for example government transfers to households, government savings, and net factor income from the rest of the world are retrieved from government and national accounts.

To be able to analyse policy impacts via the energy system, several of the energy-related sectors in the SAM need to be further disaggregated to the desired level of detail creating a so-called Energy SAM (ESAM). An ESAM expands the SAM to include energy inputs explicitly and the concomitant emissions from energy use; in other words fuel combustion. Several energy-related sectors of the SAM are disaggregated into specific carbon commodities and industries. This process involves distributing the total value of the original sector over the newly created subsectors for the activity and commodity rows and columns in the SAM. The disaggregation process requires not only obtaining information on production activities intermediate input demand composition and the composition of value added by factors of production but also distribution of final consumption across private (household) consumption, public consumption, consumption by investment purposes (investment by origin) and exports.

Although the I3E model mainly focuses on the energy-economy interaction, the SUTs for the Irish economy are quite restrictive regarding the level of details for the energy-related sectors due to data confidentiality concerns. For instance, as there is only one refinery in the country, the Central Statistical Office (CSO) merges the petroleum sector with the furniture and other manufacturing sector, and provides highly aggregated data on the merged sector. The commodities produced by these quite distinct sectors are also provided in aggregate figures. The same aggregation is also a problem for the mining and quarrying sector, which produces peat and coal and extracts natural gas, which are commodities with different carbon contents affecting their emissions and the taxation policy applied to them. As explained in Section 5, extensive use is made of EUROSTAT and EXIOBASE datasets, as well as Energy Balance (EB) from the Sustainable Energy Authority of Ireland (SEAI) and the Business Energy Use Survey of CSO.

Lastly, in order to analyse the distributional impacts of policy changes, the private household sector is disaggregated into 10 distinct representative household groups (RHGs, five in rural areas and five in urban areas) based on disposable income. The total labour force is also disaggregated into low-, medium-, and high-skilled labour based on attained level of education. In the disaggregation process of the households, the HBS, the Survey on Income and Living Conditions (SILC) and the Labour Force Survey (LFS) are used extensively. Details of the disaggregation procedure are discussed in Section 6. 


\section{Aggregated Social Accounting Matrix}

This section is devoted to explaining the construction of the Irish ESAM; see Table 1 for an aggregated version. In the following subsections, the details of each account and the relationship between the agents are summarized.

The SUTs for Ireland consist of 58 industries and 58 products. These production sectors are firstly merged into 29 sectors based on their shares in total value added, employment and emissions. Subsequently, as explained in detail in Section 5, three sectors are further disaggregated, and the total number of sectors / activities in the I3E model reaching 32. The products are merged into 39 commodities based on their economic or environmental importance. Out of 39 commodities, 37 are domestically produced in Ireland while two of them (crude oil and coal) are imported in their entirety. The list of activities and commodities in the SAM can be found in Appendix B.

Notice that the columns of a SAM show the expenditures of the account whereas the rows consist of the incomes of the account. For the sake of simplicity, the notation $(\mathrm{x}, \mathrm{y})$ will be used where $x$ stands for the row account and $y$ stands for the column account.

\subsection{Activities - ACT}

The account Activities (ACT) produces commodities by using commodities as intermediate inputs and factors of production, and pays a production tax over the value of the production. Total domestic production, which is equal to the sum of the Supply Table is consumed by the Commodities (COM) account. In other words, the account COM buys all products from the ACT account, and this comprises the income of the ACT account. Thus, this value appears in the cell (ACT,COM).

The column of the ACT account shows the cost structure of the production sectors. The total value of intermediate input demand, which is the income of the COM account, appears in the cell (COM,ACT). The sectors make payments to the factors of production, which are capital (CAP,ACT), low-skilled labour (LSL,ACT), medium-skilled labour (MSL,ACT) and high-skilled labour (HSL,ACT). The figure in the cell (CAP,ACT) directly comes from the Use Table's corresponding row sum. The sum of the payments to the labour types, which is also directly available in the Use Table, is disaggregated into payments to types of labour by using the Survey on Income and Living Conditions (SILC). ${ }^{3}$

The only information not available in the Use Table is the activities' payments to the rest of the world account (RoW), which corresponds to half of the cost of the European Union Emission Trading System (EU-ETS). In the current legislation, around half of the cost of the ETS is paid to the government and the remainder goes to the EU Commission. Half of the total cost of the ETS (around $€ 80$ million) is put in the cell (RoW,ACT) and this amount is deducted from the original 'Net taxes (taxes minus subsidies) on production' in the Use Table, and the remaining value, the cell (PT,ACT), is the production tax payments of the activities.

3 See Section 4.4 for further details. 


\subsection{Commodities (COM) and Margins (MAR)}

The row of the account of Commodities (COM) shows the components of total demand; the intermediate input demand (COM,ACT), trade and transportation margin demand (COM,MAR), government demand (COM,GOV), household (including Non-profit Institutions Serving Households-NPISH) demand $(\mathrm{COM}, \mathrm{HH})$, investment demand including changes in inventories (COM,S-I) and, finally, export demand (COM,RoW). All these values come from the corresponding columns of the Use Table. In the national accounts, in-kind transfers from the government to households are excluded from household consumption but included in public consumption. In the SAM, the value of in-kind transfers retrieved from the government accounts is added (subtracted) to (from) private (public) consumption.

Trade and transportation services are necessary to deliver commodities from factories and docks to markets. Producer prices do not comprise the cost of these margins since these are not part of the production process. These costs are paid by final users of commodities and are included in purchaser prices. On the Supply Table, the values in the column of margins are entered as negative for trade and transportation activities and they are positive for all other activities; the column sum is equal to zero. The reason for this is that trade and transportation activities are the producers of these intermediation services while the other sectors demand these services. The sum of margin demands - the sum of positive values on the margin column of the Supply table - appears in the cell (COM,MAR). The sum of negative values of the same column appears in the cell (MAR,COM) as these services are demanded by commodities, since a commodity is produced by several activities and the cost of margins is paid by consumers.

The column of the account of COM shows the sources of supply; the domestic production (ACT,COM), margin demand (MAR,COM), sales / value added tax on the total domestic demand (ST,COM), carbon tax collected on the domestic demand of the energy commodities (CT,COM) and, finally, import demand (RoW,COM).

\subsection{Capital - CAP}

The Capital account collects gross payments to capital, which equal the sum of net operating surplus and the consumption of fixed capital in the Use Table. Since this is the income of the Capital account, the value is in the cell (CAP,ACT).

The account pays a direct tax to the account of DT (DT,CAP), which is equal to the corporate tax collection of the government. This value is calculated as a residual by subtracting income tax collection from the sum of the total direct tax and capital tax revenue of the government. In other words, it includes capital acquisitions tax, capital gains tax, corporation tax, local property tax, other current direct taxes, and capital taxes. The net-of-tax capital income goes to the account of Enterprises (ENT,CAP), which is the owner of all production activities. The reason for introducing such an account is to simplify some details of the model; this solves the issue of a lack of sector-specific data such as corporate tax payments. 


\subsection{Labour Types - LSL, MSL and HSL}

The accounts of different labour types collect gross wage income from the activities (L,ACT) and pay the wage income tax to the account of Direct Tax (DT,L), where $L$ stands for each labour account, LSL, MSL and HSL. The net-of-tax amount goes to households as net wage income (HH,L). The total value of direct tax income of labour types is equal to the income tax revenue of the government.

These labour types are created by using the SILC data based on attained level of education. For instance, individuals with no formal/ primary or lower secondary education are assumed to be low-skilled, individuals who have an upper secondary, post Leaving Certificate or third level without a degree are assumed to be medium-skilled, and lastly, individuals with a third-level degree or above are assumed to be high-skilled. Then, for each type of household defined in the model, the composition of wage income by skills is retrieved: the share of labour income of each type of labour in total wage income of each RHG. In this analysis, individuals under age 16 or without information concerning attained education are excluded.

The SILC also provides the economic sector of employment by NACE codes for each working individual, but the sectoral classification of the survey is quite restrictive, especially for manufacturing and transportation sectors. To have more accurate results on the sectoral wage costs, the Labour Force Survey (LFS) is utilised by using the same mapping of the attained level of education and the skill types defined in the model. Then, the share of each type of labour in the total sectoral employment can be estimated.

\subsection{Enterprises - ENT}

As mentioned before, the account is the owner of all production activities. It collects the net capital income from the capital account (CAP,ENT) and transfers from the government. The value of government transfers is calculated as residual to ensure the government account is in equilibrium. The value, on the other hand, is quite close to the sum of the following items in the government accounts: other current transfers, capital transfers and net acquisition of non-financial assets.

Total income is split between payments to households as net-of-tax capital income (HH,ENT) in the form of dividends and corporate savings (S-I,ENT). The corporate savings are collected from the Quarterly Accounts of Institutional Sectors (QAIS). Payments to households are calculated as a residual.

\subsection{Government - GOV}

All tax accounts pay their revenues to the government account (GOV,T), where $T$ stands for each tax account, PRT, ST, CT, and DT.

Government expenditure consists of public demand of commodities (COM,GOV), transfers to enterprises (ENT,GOV), unilateral welfare and pension transfer to households (HH,GOV) and interest payments over the outstanding foreign debt stock to the rest of the world (RoW,GOV).

The difference between total government income and expenditure represents public saving, which is equal to operating surplus / deficit value in the government accounts appears in the cell (S-I,GOV). 
Table 1: Aggregated SAM of Ireland for the year 2014, €billion

\begin{tabular}{|c|c|c|c|c|c|c|c|c|c|c|c|c|c|c|c|c|c|}
\hline & $\mathrm{ACT}$ & $\mathrm{COM}$ & MAR & CAP & LSL & MSL & HSL & PRT & ST & $\mathrm{CT}$ & DT & ENT & GOV & $\mathrm{HH}$ & S-I & RoW & Total \\
\hline $\mathrm{ACT}$ & & 417.95 & & & & & & & & & & & & & & & 417.95 \\
\hline $\mathrm{COM}$ & 240.95 & & 25.46 & & & & & & & & & & 26.24 & 87.08 & 45.16 & 216.90 & 641.79 \\
\hline MAR & & 25.46 & & & & & & & & & & & & & & & 25.46 \\
\hline CAP & 102.99 & & & & & & & & & & & & & & & & 102.99 \\
\hline LSL & 7.72 & & & & & & & & & & & & & & & & 7.72 \\
\hline MSL & 29.46 & & & & & & & & & & & & & & & & 29.46 \\
\hline HSL & 36.06 & & & & & & & & & & & & & & & & 36.06 \\
\hline PRT & 0.74 & & & & & & & & & & & & & & & & 0.74 \\
\hline ST & & 17.14 & & & & & & & & & & & & & & & 17.14 \\
\hline $\mathrm{CT}$ & & 0.39 & & & & & & & & & & & & & & & 0.39 \\
\hline DT & & & & 8.10 & 0.72 & 10.40 & 17.02 & & & & & & & & & & 36.24 \\
\hline ENT & & & & 94.89 & & & & & & & & & 5.95 & & & & 100.85 \\
\hline GOV & & & & & & & & 0.74 & 17.14 & 0.39 & 36.24 & & & & & & 54.51 \\
\hline $\mathrm{HH}$ & & & & & 7.00 & 19.06 & 19.05 & & & & & 56.71 & 28.08 & & & -29.72 & 100.17 \\
\hline S-I & & & & & & & & & & & & 44.14 & -7.10 & 13.09 & & -4.97 & 45.16 \\
\hline RoW & 0.04 & 180.85 & & & & & & & & & & & 1.33 & & & & 182.21 \\
\hline Total & 417.95 & 641.79 & 25.46 & 102.99 & 7.72 & 29.46 & 36.06 & 0.74 & 17.14 & 0.39 & 36.24 & 100.85 & 54.51 & 100.17 & 45.16 & 182.21 & \\
\hline
\end{tabular}

ACT: Activities; COM: Commodities, CAP: Capital; LSL: Low-skilled labour; MSL: Medium-skilled labour; HSL: High-skilled labour; MAR: Trade and transportation margins; PRT: Production tax; ST: Sales tax; CT: Carbon tax; DT: Direct tax; GOV: Government; HH: Households; ENT: Enterprises; S-I: Saving-Investment; RoW: Rest of the world. 
The value of interest payments to the rest of the world is calculated by subtracting the change in the foreign debt stock of the government (retrieved from the National Treasury Management Agency) from the interest payments (excluding financial intermediation services indirectly measured - FISIM) of the government. Accordingly, the government foreign debt stock increased by $€ 6.3$ billion between 2014 and 2013, while the its interest payment was $€ 7.6$ billion in 2014 . The net payment of the government to the rest of the world is positive and appears in the cell (RoW,GOV). As all information comes from the government accounts, the cell (ENT,GOV) is used as a residual account to balance the government accounts.

It should be noted that the total revenue of the government in the SAM is less than its realised value in 2014 by around $€ 11$ billion. The reasons for this difference can be explained as follows. First, the total amount of indirect taxes (taxes on production and consumption) is $€ 18.27$ billion in the SUTs while it is $€ 21.21$ billion in the government accounts. The difference of $€ 2.94$ billion can be attributed to subsidies on production and commodities. The remaining difference, $€ 8.5$ billion, is equal to the sum of the following items in the government account: sales of goods and services, investment income, current transfer revenue, and capital transfer revenue. The recipient of sales of goods and services is the activity of public services, which is defined as a separate production activity (sector) in the I3E model. The remaining items are ignored as the I3E model does not have specific agents that are payers or recipients of these income items. In order to ensure the balance of the government account, the total expenditure is set to equal the total of revenue and the transfer to enterprises is used as a residual account.

\subsection{Households - HH}

Households have net-of-tax wage income from the labour accounts (HH,L) where $L$ stands for the labour types, dividend income from the enterprises (HH,ENT), transfer (including pension income) from the government (HH,GOV), and net factor income from the rest of the world (HH,RoW). The value of the last item is readily available in the national accounts. The sum of these items yields household disposable income as all items are in net-of-tax terms. Households devote their disposable income to private consumption $(\mathrm{COM}, \mathrm{HH})$ or to saving $(\mathrm{S}-\mathrm{I}, \mathrm{HH})$, which is calculated as residual to hold the balance of the account of HH. The HBS is used extensively in the calibration process of household-level parameters. For further information, see Section 6.

\subsection{Rest of the World - RoW}

As in the case of all single-country CGE models, all countries except Ireland are assumed to be a single unit referred to as the 'rest of the world'. All monetary flows between the rest of the world and Ireland are traced within the rest of the world (RoW) account. Since all transactions related to this account are assumed to be denominated in a foreign currency, an exchange rate adjustment takes place. In the case of Ireland, although there is no exchange rate discrepancy for the transactions within the EU, almost two-thirds of the value of foreign trade consists of trade flows between Ireland and the United States and 
Ireland and the United Kingdom. As there is no distinction between these trade partners within the I3E model, the exchange rate movements also play an important role.

The account receives half of the cost of ETS permits paid to the European Commission (RoW,ACT), imports of commodities (RoW,COM), and the government interest payments over the outstanding foreign debt stock (RoW,GOV). The account's expenditures consist of exports of commodities (COM,RoW) and net factor income of households (HH,RoW). The difference between the row sum and the column sum yields the net foreign exchange demand of an economy - the current account balance. Its positive value indicates that the country runs a current account deficit. In the case of Ireland, this value is $-€ 4.97$ billion, which means that the country has a current account surplus. In other words, the value is negative since the current account is the net outflow of savings abroad.

The realised value of the current account surplus for the year of 2014 was $€ 6.8$ billion. As explained in Section 4.6, the model has to ignore some income streams because the data used to construct the SAM come from different sources, and there are some discrepancies across these.

\subsection{Savings-Investment - S-I}

The receipts of the account of Savings-Investment are corporate savings (S-I,ENT), private savings (S$\mathrm{I}, \mathrm{HH}$ ), government savings (S-I,GOV) and the foreign savings (S-I,RoW). Since the total amount of savings is used to finance the investment expenditures in the economy, the only expenditure item of the account is commodity demand for investment purposes (COM,S-I). Since all other accounts are in equilibrium, the value of foreign savings also equilibrates the saving / investment balance.

\section{Energy Sector Disaggregation Process}

To be able to analyse impacts via the energy system, several of the energy-related sectors (activities and commodities) in the CSO SUTs need to be further disaggregated to the desired level of detail. The disaggregation entails creating multiple sectors from a single sector including: Mining, Quarrying, and Extraction (MQE - NACE 5-9), Petroleum, Furniture and Other Manufacturing (PFOM - NACE 19, 31, 32) and Electricity and Gas Supply (EGS - NACE 35).

In the case of MQE, a distinction needs to be made between crude oil, peat, coal, natural gas and other mining sectors. Other mining includes metal ore, stone, sand, and clay. PFOM has been aggregated to avoid data confidentiality issues. This sector needs to be disentangled from furniture and other manufacturing and further disaggregated into diesel, gasoline, kerosene, fuel oil, LPG and other petroleum products. EGS needs to be disaggregated into electricity services and gas services.

The disaggregation process involves distributing the total value of the original sector over the newly created subsectors for the activity and commodity rows and columns in the SUTs. The disaggregation process requires not only obtaining information on production activities, including, intermediate input demand composition and the composition of value added by factors of production, but also distribution 
of final consumption across private (household) consumption, public consumption, consumption by investment purposes (investment by origin), and exports.

The disaggregation relies heavily on two data sources: the 2014 Irish Energy Balance (EB) published by the SEAI and the 2014 Business Energy Use Survey (BEUS) published by the CSO. The EB presents national energy statistics on energy production and consumption in Ireland. The flow of energy from production, transformation and the energy sectors' own use through to final consumption in different sectors of the economy is given in energy units (ktoe). These energy units are converted into tonnes and monetary units using different fuel prices derived from the SEAI domestic and commercial fuel costs archives and the IEA fuel costs data for Ireland. The BEUS is an annual survey conducted by the CSO that collects information about energy use by businesses in Ireland. This survey presents both the energy use of different fuels and sectors in energy units as well as in monetary costs. The BEU provides the latest data concerning business energy use and will be used in the future to update the EB.

Once the energy sector is disaggregated, the I3E will be able to explicitly include carbon commodities (peat, coal, natural gas, gasoline, gas oil, fuel oil, kerosene, and other petroleum products), which are used by the various production sectors or consumed directly by final users. In this way, carbon and carbon emissions can be tracked through the various production and consumption channels.

In what follows, we discuss the disaggregation process of each energy-related sector in turn.

\subsection{Petroleum and Furniture}

In the SUTs for Ireland, the petroleum sector (NACE 19) is combined with the furniture and other manufacturing sector (NACE 31 and 32) to create the PFOM sector. This has been done to avoid data confidentiality issues, where the petroleum sector is dominated by a single firm. CSO data from 2011 concerning output and value added are used as well as EUROSTAT data, to disaggregate these sectors.

\subsubsection{Supply Table disaggregation}

The CSO does provide data for 2011 for the petroleum and chemicals sectors (NACE 19, 20) and the furniture and other manufacturing sector (NACE 31 and 32) separately concerning market output, intermediate consumption, gross value-added and taxes on product less subsidies. Using the 2011 supply table data for the chemical sector (NACE 20), the level of these variables for the petroleum sector can be estimated. Where output for the petroleum sector is given as:

$$
X_{p e t}=X_{p c h}-X_{c h}
$$

where $X_{p c h}$ represents the output for the combined petroleum and chemicals sector (as given in the 2011 CSO output data), $X_{c h}$ is the output for the chemicals sector (obtained from the 2011 SUTs) and $X_{p e t}$ is the estimated output for the petroleum sector. 
For gross value added, intermediate consumption and taxes on product less subsidies, the same approach is used:

For gross values added:

$$
V A_{p e t}=V A_{p c h}-V A_{c h}
$$

For intermediate consumption:

$$
\begin{gathered}
I C_{p e t}=I C_{p c h}-I C_{c h} \\
I C_{p e t}=\sum_{c} Z_{c p e t}
\end{gathered}
$$

and for taxes on product less subsidies (net tax on production):

$$
T A X_{p e t}=T A X_{p c h}-T A X_{c h}
$$

We later use these estimated variables to capture the relative sizes of the petroleum and furniture and other manufacturing sectors in Ireland compared to other EU countries.

EUROSTAT provides supply tables for various EU countries and the EU27 and EA19, the monetary union. ${ }^{4}$ Comparing the energy balances of the various EU countries, the EU27 and EA19 with that of Ireland, we believe that the EA19 best represents the energy structure of Ireland. For the disaggregation process, it is assumed that the EA19 flows can approximate the Irish relative flows within the economy from and to the petroleum and furniture and other manufacturing. In other words, for example $50 \%$ of PFOM commodities in the EA19 are used (for example, manufacturing chemicals), it is assumed that 50\% of the Irish petroleum commodities are also used in the manufacturing of chemicals. Moreover, if in the EA19, $20 \%$ of total commodities produced by the petroleum sector are chemicals, $20 \%$ of commodities produced by the petroleum sector in Ireland are assumed to be chemical products.

Concerning the estimation of product sales in the supply table, to distinguish the share of each commodity produced by the activity PFOM that is designated as being produced by petroleum, both the estimated output of the petroleum and furniture and other manufacturing sectors and the share of each commodity's production in total production (output) in each sector in the EA19 are used. The share of each commodity in total production by the petroleum activity is referred to here as the supply table commodity share and is calculated as follows:

$$
\operatorname{scs}_{E U \text { petc }}=\frac{X_{\text {EUpetc }}}{\sum_{c} X_{E U \text { petc }}}
$$

where $X_{E U \text { petc }}$ represents the value of commodity $c$ produced by the activity petroleum, given in the EUROSTAT EA19 supply table for 2014. The share for furniture and other manufacturing is calculated in the same way.

4 Austria, Belgium, Cyprus, Estonia, Finland, France, Germany, Greece, Ireland, Italy, Latvia, Lithuania, Luxembourg, Malta, Netherlands, Portugal, Slovakia, Slovenia, and Spain. 
The share of each commodity produced by the activity PFOM that is designated as being produced by petroleum is then given by:

$$
s s_{\text {petc }}=\frac{X_{\text {pet }} s c s_{\text {petc }}}{X_{\text {petc }} \operatorname{scs} s_{E U \text { petc }}+X_{f m} \operatorname{scs} E U f m c}
$$

where $X_{f m}$ and $X_{p e t}$ represent the output for the furniture and other manufacturing and petroleum sectors respectively in 2011, as calculated above. $\operatorname{scs}_{E U f m c}$ represents the supply table commodity share for the furniture and other manufacturing sector. In this way, we weight the EA19 shares by the relative magnitudes of the furniture and other manufacturing and petroleum sectors in Ireland.

The remainder is designated as furniture and other manufacturing:

$$
s s_{f m c}=1-s s_{p e t c}
$$

The share of the PFOM commodities produced by the different activities that is designated as petroleum commodities (in the supply table rows) is calculated similarly by first calculating the EA19 supply table activity share:

$$
\text { sas }_{\text {EUapet }}=\frac{X_{\text {EUapet }}}{\sum_{a} X_{\text {EUapet }}}
$$

The share of the PFOM commodities produced by the different activities that is designated as petroleum commodities is then calculated as follows:

$$
s s_{\text {apet }}=\frac{X_{\text {pet }} \text { sas }_{\text {EUapet }}}{X_{\text {pet }} \text { sas }_{\text {EUapet }}+X_{f m} \text { sas }_{E U a f m}}
$$

The remainder is designated as furniture and other manufacturing:

$$
s s_{a f m}=1-s s_{\text {apet }}
$$

For the case of flows from petroleum and furniture and other manufacturing to themselves and each other, the share is calculated differently as follows, where for example the share of the PFOM produced by the petroleum activity is estimated by first estimating the EA19 share:

$$
\begin{aligned}
& \text { sas }_{\text {EUpetpet }}=\frac{X_{\text {EUpetpet }}}{X_{\text {EUpetpet }}+X_{E U \text { petfm }}+X_{E U f m f m}+X_{E U f m p e t}} \\
& s s_{E U \text { petpet }}=\frac{X_{\text {pet }} \text { sas }_{\text {EU petpet }}}{X_{\text {pet }}\left(\text { sas }_{\text {EU petpet }}+\operatorname{sas}_{\text {EU pet } f m}\right)+X_{f m}\left(\operatorname{sas}_{E U f m f m}+\operatorname{sas}_{E U f m p e t}\right)}
\end{aligned}
$$

Note that the bulk of production in each activity falls in the corresponding commodity: almost all of the production of activity petroleum concerns the commodity petroleum. 
The trade margins for the commodities are not given for the EA19. In this case, we have used data for the EA19 countries for which data are available. ${ }^{5}$ First the shares of trade margins in total supply for each sector is calculated:

$$
\begin{aligned}
& s m_{\text {EU pet }}=\frac{M_{\text {EUpet }}}{Z_{E U p e t}} \\
& s m_{E U f m}=\frac{M_{E U f m}}{Z_{E U f m}}
\end{aligned}
$$

where $M_{E U \text { pet }}$ is the sum of the payments of EA19 countries by the petroleum commodity to margins, and $Z_{E U \text { pet }}$ represents the sum of the EA19 countries' total supply.

The share of total trade margins for PFOM that is designated to the petroleum commodity is then:

$$
s m_{p e t}=\frac{X_{p e t} s m_{E U p e t}}{X_{p e t} s m_{E U p e t}+X_{f m}\left(s m_{E U f m}\right.}
$$

The imports of and sales taxes on petroleum products are directly calculated based on the $2014 \mathrm{~EB}$ and CSO trade data, where the remainder of the PFOM totals are designated as pertaining to the furniture and other manufacturing sector. This is described in more detail in the next section.

\subsubsection{Use Table disaggregation}

For disaggregating the use table, we use the same approach as in the case of the supply table. EUROSTAT, however, does not provide the use table at purchaser prices but at basic prices: purchaser prices are the sum of basic prices, net taxes on products, trade and transport margins and non-deductible VAT. This use table needs to be converted from basic to purchaser prices. To do this, the data concerning the use table in both basic and purchaser prices for the EA19 countries for which these data are available are collected. ${ }^{6}$ A basic-to-purchaser multiplier is calculated for each of these countries (given by N) for each commodity and activity combination for the petroleum sector and furniture and manufacturing sectors. The example of the petroleum sector is shown here, where the basic-to-purchaser price multiplier is given as:

For the activity petroleum:

$$
\text { bpm }_{\text {ncpet }}=\frac{Z P P_{\text {ncpet }}}{Z B P_{\text {ncpet }}}
$$

where $Z P P_{\text {ncpet }}$ are the values in the use table for country $n$ commodity $c$ for activity petroleum at purchaser prices and $Z B P_{n c p e t}$ at basic prices.

We then take the average multiplier by dividing the sum of these by the number of countries for which there is data $(\mathrm{N})$ :

$$
\operatorname{bpm}_{\text {EU pet }}=\frac{\sum_{n} b p m_{n c p e t}}{N}
$$

\footnotetext{
5 Austria, Belgium, Cyprus, Estonia, Finland, France, Germany, Greece, Italy, Luxembourg, Netherlands, Portugal, Slovakia, Slovenia, and Spain.

6 Estonia, France, Italy, Netherlands, Portugal, Slovenia.
} 
For the commodity petroleum:

$$
\text { bpm }_{\text {npeta }}=\frac{Z P P_{\text {npeta }}}{Z B P_{\text {npeta }}}
$$

We then take the average multiplier by dividing the sum of these by the number of countries:

$$
\text { bpm }_{\text {EU peta }}=\frac{\sum_{n} b_{p m_{\text {npta }}}}{N}
$$

Using these multipliers, the EUROSTAT EA19 use table at basic prices is converted to purchaser prices. Finally, these multipliers are adjusted such that the relative shares of intermediate consumption for the petroleum and furniture and other manufacturing sectors hold (as calculated using 2011 CSO data):

$$
i c s_{p e t}=\frac{I C_{p e t}}{I C_{p e t}+I C_{f m}}
$$

This is done by multiplying each multiplier for each sector by the same factor; in other words all petroleum multipliers are multiplied by the same factor. Following this, this converted EUROSTAT use table in purchaser prices is applied to disaggregate the CSO use table for the PFOM sector.

Concerning the estimation of intermediate demand, the share of each commodity used by the activity PFOM that is designated as being used by the activity petroleum is calculated by first calculating the EA19 use table (in purchaser prices) activity share of intermediate consumption, which represents the share of commodity $c$ in total intermediate demand by activity petroleum, and given by:

$$
u_{\text {EUcpet }}=\frac{Z_{\text {EUcpet }}}{\sum_{c} Z_{\text {EUcpet }}}
$$

where $Z_{\text {EUcpet }}$ represents the value of commodities used by the activity petroleum in the converted EUROSTAT EA19 use table for 2014.

These shares are then weighted by the relative shares of the petroleum and furniture and other manufacturing sectors in intermediate consumption in 2011 given by the CSO. The share of commodities used by the PFOM sector that is designated as being used by petroleum is hence calculated as follows:

$$
u s_{c p e t}=\frac{I C_{p e t} u c s_{E U c p e t}}{I C_{p e t} u c s_{E U c p e t}+I C_{f m} u c s_{E U c f m}}
$$

The remainder is designated as furniture and other manufacturing:

$$
u s_{c f m}=1-u s_{c p e t}
$$

The share of the PFOM commodities used by the different activities that is designated as petroleum commodities is similarly estimated by first estimating the EA19 use table activity share of intermediate consumption, which represents the share of activity $a$ in total intermediate demand of the petroleum commodity: 


$$
\begin{aligned}
& \text { uas }_{\text {EU peta }}=\frac{Z_{E U \text { peta }}}{\sum_{a} Z_{E U \text { peta }}}
\end{aligned}
$$

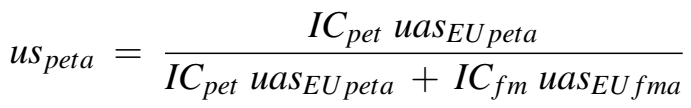

The remainder is designated as furniture and other manufacturing:

$$
u s_{f m a}=1-u s_{p e t a}
$$

For the case of flows from petroleum and furniture and other manufacturing to themselves and each other, the share is calculated differently as follows, where for example the share of the PFOM used by the petroleum activity is given by:

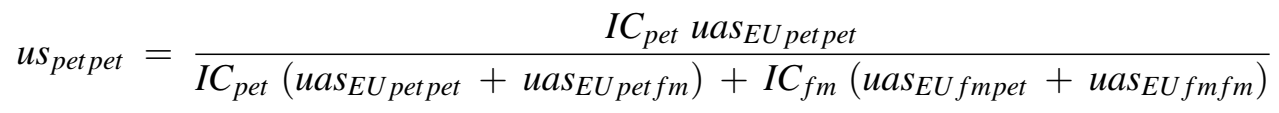

Concerning the shares of value-added, total gross value added (GVA) of PFOM is directly divided across the petroleum and furniture and other manufacturing sectors based on their gross value added provided for 2011. The share of the petroleum sector is then given as:

$$
v_{\text {aset }}=\frac{V A_{\text {pet }}}{V A_{\text {pet }}+V A_{f m}}
$$

The operating surplus, net taxes, and consumption of fixed capital - the elements of GVA are also divided based on the levels of GVA for each sector.

Total final uses are calculated as the total uses (which is total supply in the supply table) minus total inter-industry demand (which is the sum of intermediate consumption over products). Total final uses $(f u)$ are then divided among the final uses (consumption of households, NPISH, government consumption, gross fixed capital formation, change in inventories, and exports) based on their shares in total final uses for the EA19.

$$
F U_{\text {fupet }}=\frac{T F U_{\text {pet }} F U_{\text {EUfupet }}}{T F U_{\text {EUpet }}}
$$

Some of the final use elements are later adjusted when disaggregating petroleum products if more reliable data are available. This is discussed in the next section.

\subsection{Petroleum products}

The petroleum sector represents a single activity or industry. The petroleum commodities, however, need to be further disaggregated into gasoline, kerosene, fuel oil, LPG, diesel and other petroleum products. This is done based on the Irish EB published by the SEAI and the CSO's BEUS. 
Table 2: IEA fuel costs data for Ireland

\begin{tabular}{|l|r|r|r|r|}
\hline Fuel type & Price $(€ /$ toe, excl. taxes $)$ & Source & Emissions coefficient $\left(\mathrm{tCO}_{2} / \mathrm{TJ}\right)$ & Source \\
\hline Gasoline & 783.3 & IEA & 70.0 & SEAI \\
Kerosene & 741.1 & IEA \& SEAI & 71.4 & SEAI \\
Fuel Oil & 771.4 & IEA & 73.3 & SEAI \\
LPG & 657.8 & IEA \& SEAI & 63.7 & SEAI \\
Diesel & $1,048.0$ & IEA & 73.3 & SEAI \\
\hline
\end{tabular}

We convert the EB into tonnes and monetary units using different fuel prices derived from the SEAI domestic and commercial fuel costs archives and the IEA fuel costs data for Ireland. In Table 2, the prices for each fuel type used and the source are given, as well as the conversion factors used to calculate the fuel-specific $\mathrm{CO}_{2}$ emissions.

Disaggregating the supply table, we first disaggregate the supply of petroleum products produced by the petroleum sector. The above-calculated share of petroleum commodity produced by petroleum $\left(s s_{\text {petpet }}\right)$ is divided among the different petroleum products (given by $p p$ ). This is based on the estimated monetary values of the EB of transformation output of refineries, calculated by:

$$
T S_{p p}=p_{p p} S O R_{p p}
$$

where $p_{p p}$ is the price of the petroleum product $\mathrm{pp}$ in $€ / \mathrm{ktoe}$ and $S O R_{p p}$ is the quantity of supply by oil refineries in ktoe of $p p$. The supply share for each petroleum product is given as:

$$
s s_{p e t p p}=\frac{S O R_{p p}}{\sum_{p p} S O R_{p p}}
$$

For disaggregating the supply of petroleum commodities by other activities (which is extremely small), we apply the EXIOBASE dataset (Version 2.2.2). EXIOBASE is a global, detailed Multi-regional Environmentally Extended Supply and Use / Input-Output database. It was developed by harmonising and detailing SUTs for a large number of countries. This dataset focus on resources and includes a detailed disaggregation of the petroleum sector for Ireland. We calculate the share of each petroleum product in supply by:

$$
s s_{a p p}=\frac{S_{a p p}}{\sum_{a} S_{a p p}}
$$

where $S_{a p p}$ is the supply of the petroleum product by activity $a$ in EXIOBASE.

To disaggregate the use table, we use the same approach but apply the BEUS data to determine which activities use which petroleum products. We divide the total use of petroleum products across the various products assuming the same shares as in the BEUS monetary data. Where our estimates of total petroleum product use differ significantly from those of the BEUS, our petroleum/furniture and other manufacturing shares are adjusted to replicate the BEUS estimates. 
Total intermediate uses are used to divide the total share:

$$
u s_{a p p}=\frac{I_{a p p}}{\sum_{p p} I U_{a p p}}
$$

where $I U_{\text {app }}$ represents intermediate uses in monetary terms for each activity by petroleum product.

Imports are estimated based on both the EB and CSO import data, which give the value of imports for different product types defined using the Standard International Trade Classification (SITC, Rev 4). The aggregated CSO import data concerning petroleum, petroleum products and related material (SITC 33) are shared among the various petroleum products based on the monetary EB estimates. ${ }^{7}$ Taxes on petroleum products are taken from the Revenue Commissioners' tax receipt data, which give carbon and other taxes on the different petroleum products.

\subsection{Mining and quarrying}

The MQE sector composes of various mining activities. It needs to be disaggregated into other mining, peat, coal, natural gas and crude oil. To disaggregate the different mining sectors, the EXIOBASE dataset (Version 2.2.2) and the 2007 CSO SUTs are utilised. In earlier CSO SUTs (up to 2007), a distinction was made 'mining' (coal, peat, crude oil, natural gas and metal ore extraction) and 'ther mining' (any other mining). EXIOBASE data display the same relative split between mining and other mining as the CSO data. These data are adjusted based on the EB to account for the relative decrease in natural gas production between 2007 and 2014. As will be discussed in the description of the EGS further on, it is assumed that natural gas used by activities is directly supplied by the natural gas extraction sector here. Furthermore, natural gas imports are also accounted for in the MQE sector.

\subsubsection{Supply Table disaggregation}

Coal and crude oil are not extracted in Ireland; hence hence these sectors do not have a share in MQE domestic supply. All supply is imported. Coal and crude oil do not represent an activity and are only disaggregated as commodities. We define the different mining activities and commodities are defined as min; these are coal, crude oil, peat, natural gas and other mining (though coal and crude oil are omitted in the supply case).

The supply table is disaggregated by assuming the same relative shares as EXIOBASE and the EB. The share of each commodity produced by MQE activity that is designated as being produced by each activity $\min$ is given by:

$$
s s_{\text {minc }}=\frac{X_{\text {Exiominc }}}{\sum_{\text {min }} X_{\text {Exiominc }}}
$$

where $X_{\text {Exiominc }}$ represents the value of commodity $c$ produced by activity min given by EXIOBASE.

\footnotetext{
7 Note that this category also includes crude oil, which falls under the mining sector and hence is excluded here.
} 
The share of MQE commodities produced by the different activities that is designated as being each min commodity (in the supply table) is similarly given by:

$$
s s_{\text {amin }}=\frac{X_{\text {Exioamin }}}{\sum_{\min } X_{\text {Exioamin }}}
$$

Regarding the case of flows from the mining sectors to themselves (hence the supply of mining commodities by mining activities), the CSO 2007 split between energy mining (natural gas and peat) and other mining is applied first to determine their relative sizes. Here, EXIOBASE is used to subtract metal ore mining from the CSO-defined mining to obtain energy mining and then add it to other mining. Energy mining is then split between natural gas and peat by applying the EB data, which give the most accurate estimate of the domestic supply of peat and natural gas for 2014 .

The estimated monetary values of domestic production of peat and natural gas as given by the EB are calculated. The total supply in monetary terms $\left(T S_{\min }\right)$ is calculated based on the $2014 \mathrm{~EB}$ as follows:

$$
T S_{\min }=p_{\min } Q I_{\min }
$$

where $p_{\min }$ is the price of the commodity min given by the SEAI in $€ /$ ktoe and $Q I_{\min }$ is the quantity of intermediate use in ktoe of $\mathrm{min}$.

Where the total supply of energy mining are used to divide the total share of energy mining supply:

$$
s s_{\min m i n}=\frac{T_{\min }}{\sum_{\min } T S_{\min }}
$$

\subsubsection{Use Table disaggregation}

The use table disaggregation follows a similar methodology as the supply table, where the share of each commodity used by MQE activity that is designated as being used by $\min$ is given by:

$$
s u_{\text {cmin }}=\frac{Z_{\text {Exiocmin }}}{\sum_{\min } Z_{\text {Exiocmin }}}
$$

where $Z_{\text {Exiocmin }}$ represents the value of commodities $c$ used by the mining sector min given in EXIOBASE or BEUS. For the sectors/commodities for which they are available, we have used BEUS 2014 data as they are more up-to-date and reliable.

The share of MQE commodities used by the different activities that is designated as min commodities is similarly given by:

$$
s u_{\text {mina }}=\frac{Z_{\text {Exiomina }}}{\sum_{\min } Z_{\text {Exiomina }}}
$$

or the case of flows from mining activities to themselves and each other the share is calculated as follows, where the share of mining and quarrying commodities produced by mining that is designated as energy mining is similarly given by: 


$$
s u_{\text {minmin }}=\frac{Z_{\text {Exiominmin }}}{\sum_{\text {min }} Z_{\text {Exiominmin }}}
$$

Finally, the total value-added of the MQE needs to be distributed between peat, natural gas, and other mining activities. Value-added consists of four components: compensation of employees; net operating surplus; consumption of fixed capital; and net taxes on production (the term vac refers to these components). The total of these are shared between the activities based on their relative shares in the EXIOBASE data (adjusted for a decrease in natural gas production using the EB) and using CSO 2007 value-added data:

$$
v a_{\text {vaca }}=\frac{V A_{\text {Exiovaca }}}{\sum_{\text {vac }} Z_{\text {Exiovaca }}}
$$

where $V A_{\text {Exiovaca }}$ represents the value of the value-added component vac for the sector $a$ given in EXIOBASE. The same approach is used to disaggregate the final demand.

\subsection{Electricity and Gas}

The EGS (NACE 35) is disaggregated into separate gas and electricity sectors. In the SUTs, natural gas is represented both in the MQE and EGS sectors. Examining the data, it is assumed that activities are supplied with natural gas directly from the natural gas extraction sector (within MQE). Furthermore, natural gas is imported in the MQE sector. The gas supply service sector provides gas supply services, such as the transmission and distribution of gas. This sector also supplies natural gas to households and the government.

\subsubsection{Supply Table disaggregation}

The EGS sector is separated into gas and electricity using the EXIOBASE data, the BEUS data and the EB data of 2014 and price data from the SEAI.

The supply of EGS commodities by EGS is disaggregated using the same relative shares as in the EB data. Total supply in monetary terms for natural gas and electricity $\left(T S_{g a s}\right.$ and $\left.T S_{e l}\right)$ are calculated based on the 2014 EB. We show the calculations for gas, where the same approach is used for electricity, as follows:

$$
T S_{\text {gas }}=p_{\text {gas }} Q S_{\text {gas }}
$$

where $p_{\text {gas }}$ is the price of the natural gas in $€ /$ ktoe and $Q S_{\text {gas }}$ the quantity of supply in ktoe.

The gas supply commodity that is produced by the gas supply is a share of the EGS supply:

$$
s S_{\text {gas }}=\frac{T_{\text {gas }}}{T S_{\text {gas }}+T S_{e l}}
$$

The small amounts of supply from other sectors is shared among gas supply and electricity supply using the EXIOBASE shares. Imports are split using the CSO import data. 


\subsubsection{Use Table disaggregation}

EGS use is split into gas supply and electricity use. To disaggregate the column - use by the EGS sector - EXIOBASE data are used, where the same shares as in the EXIOBASE data are used. The EGS row the use by other activities of EGS - is split using the BEUS data using the monetary values. Value added is split using the EXIOBASE value-added shares. Final demand is split using the EB.

\subsection{Carbon Tax}

Carbon taxes are estimated using the Revenue Commissioners' data on tax receipts. These data give both carbon tax and other excises on solid fuels, electricity and the various oils and fuels such as gasoline, diesel, LPG. The volumes of petroleum products taxed are also compared with estimations to ensure consistency.

\section{Household Disaggregation}

In the current version of the model, 10 different household groups are defined based on their disposable income. In the HBS, the CSO provides disposable income quantiles (20 groups) separately for urban and rural areas. These households are merged into five groups in rural areas and five groups in urban areas. Following this, the HBS income items are aggregated into four groups as follows.

Table 3: Aggregation Key of the HBS Income Items to the I3E Income Items

\begin{tabular}{|l|l|l|}
\hline HBS Code & Definition & Income Item \\
\hline HE054 & Employees-wages/salaries & Wage \\
HE055 & Self-employed & Wage \\
\hline HE057 & Investment income & Capital/Asset \\
HE058 & Property income & Capital/Asset \\
HE059 & Own garden/farm produce (valued at retail prices) & Capital/Asset \\
HE060 & Other direct income & Capital/Asset \\
\hline HE056 & Retirement pensions & Pension \\
HE063 & Older people pensions & Pension \\
HE064 & Widows, widowers and guardian payments & Pension \\
\hline HE062 & Child benefit & Transfer \\
HE065 & Other long term social protection payments & Transfer \\
HE066 & Job-seekers payments (including farm assist) & Transfer \\
HE067 & Carers' payments & Transfer \\
HE068 & Education grants/scholarships/back to education allowance & Transfer \\
HE069 & Other state transfers & Transfer \\
\hline
\end{tabular}


Following this, the share of each household group in each income item (wage, asset, welfare transfer, and pension) is calculated, and these parameters are used to disaggregate the figures across households on the HH row in Table 1. The sum of income items for each household yields the disposable income of the household group - the row sum of the respective HH columns.

In the disaggregation of the column items on the HH column in Table 1, the only required information is the distribution of commodity c's consumption across household groups. To obtain the parameters to perform this disaggregation, each consumption item in the HBS is mapped to a commodity defined in the I3E model, as shown in Appendix C. In this way, total household consumption demand of each commodity can be allocated across the household types. Ensuring an accounting balance of the household accounts requires that the sum of consumption demand of each household be subtracted from the disposable income of the respective household group to get the household level private savings (S-I,HH).

\section{Emissions Trading System}

The Emissions Trading System (ETS) is the main climate policy applied in the European Union (EU). The system constructs an EU-wide carbon emission allowance market in which emission permits are traded via auctioning. ${ }^{8}$ Each installation (a production unit), except those which operate in the energy production sector, has an amount of free allowances, which is determined for the period of 2013-2020 in Phase III of the ETS. Installations for which emissions exceed their free allowances must buy additional allowances in the EU-wide allowance market at the EU-ETS price. On the other hand, if the installation emits less than its free allowance, it can sell its unused allowances on the ETS market at the EU-ETS price. In this regard, the ETS serves as either a cost or a revenue item depending on changes in the behaviour of installations concerning their carbon-intensive energy commodity demand.

Free ETS allowances cover two types of emissions; emissions related to fuel combustion and process emissions. In the I3E model, the former is calculated by multiplying the carbon content of energy commodity and the volume of intermediate demand. The latter, however, is calculated as a fixed fraction of the volume of output as the process emissions rise in the production process of other non-metallic minerals (ONM). For the air transportation sector (ATS), the other ETS emissions emerge due to the fact that the aviation emissions and the energy demand of the sector are inconsistent in the EB of Ireland. The is because the aviation firms purchase a fraction of their fuels outside of Ireland, although the entire emissions of the installations are included in the total Irish emissions.

The ETS also plays a crucial role in the I3E framework. As explained in detail in the technical document, all activities for which the sectoral emissions are fully or partially covered by the ETS internalise the cost of the ETS in their energy demand decisions. To have an accurate representation of the ETS in the I3E model, the installation-based free allowance figures and NACE codes of installations provided by the Environment Protection Agency (EPA) of Ireland are utilised. Following this, each installation is

\footnotetext{
8 In the EU-ETS terminology; the terms allowance and emission permits are used interchangeably.
} 
Table 4: ETS Figures, 2014

\begin{tabular}{|c|c|c|c|c|c|c|}
\hline & \multirow{2}{*}{ Sector } & \multicolumn{2}{|c|}{ Emissions } & \multicolumn{2}{|c|}{ Allowance } & \multirow{2}{*}{ Cost } \\
\hline & & Total & ETS & Free & Purchased & \\
\hline \multirow{13}{*}{$\begin{array}{c}\text { Energy } \\
\text { Demand } \\
\text { Related } \\
\text { Emissions }\end{array}$} & PET & 0.77 & 0.77 & 0.25 & 0.52 & 3.10 \\
\hline & ATS & 3.07 & 3.07 & 2.13 & 0.94 & 5.65 \\
\hline & ONM & 0.46 & 0.42 & 0.39 & 0.03 & 0.18 \\
\hline & CHE & 0.14 & 0.10 & 0.03 & 0.07 & 0.45 \\
\hline & BPP & 0.15 & 0.11 & 0.54 & -0.43 & -2.57 \\
\hline & BFM & 0.70 & 0.53 & 0.89 & -0.35 & -2.11 \\
\hline & FBT & 0.78 & 0.60 & 0.42 & 0.18 & 1.06 \\
\hline & HHS & 0.28 & 0.01 & 0.00 & 0.01 & 0.04 \\
\hline & SER & 0.69 & 0.02 & 0.00 & 0.02 & 0.10 \\
\hline & HTP & 0.08 & 0.06 & 0.01 & 0.05 & 0.32 \\
\hline & NGS & 1.63 & 1.20 & 0.04 & 1.15 & 6.92 \\
\hline & OTM & 0.84 & 0.65 & 0.08 & 0.56 & 3.39 \\
\hline & ELC & 8.54 & 8.54 & 0.00 & 8.54 & 51.22 \\
\hline Process & ATS & & 4.60 & 3.19 & 1.41 & 8.48 \\
\hline Emissions & ONM & & 2.32 & 2.38 & -0.07 & -0.39 \\
\hline \multicolumn{2}{|c|}{ Total } & 18.11 & 22.98 & 10.34 & 12.64 & 75.83 \\
\hline \multicolumn{2}{|c|}{ Realized Values } & & 23.29 & 9.73 & 13.56 & \\
\hline
\end{tabular}

Note: All emission figures are in million tonne equivalent $\mathrm{CO}_{2}$. The cost is in million Euro terms.

mapped to an I3E sector, and their free allowances are aggregated. Table 4 shows free allowance, ETS emissions calculated in the I3E, amount of purchased allowance and cost of ETS for each activity. 


\section{Appendix A Valuation}

Trade and transportation margins and net taxes on products (taxes minus subsidies) comprise one of the basic components of the valuation process. EUROSTAT (1995) distinguishes between two main valuation concepts of the flows of goods and services: purchaser prices and basic prices.

- Purchaser prices is the price the purchaser actually pays for the products. It includes any taxes less subsidies on the products (but excluding deductible taxes like a value-added tax (VAT) on the products); and any transport charges paid separately by the purchaser to take delivery at the required time and place. Since final consumers confront that price in the market, it also corresponds to the commodity's retail price.

- Basic prices is the price receivable by the producer from the purchaser for a unit of a good or service produced. It is output minus any tax payable on that unit as a consequence of its production or sale (taxes on products), plus any subsidy receivable on that unit as a consequence of its production or sale (subsidies on products). It excludes any transport charges invoiced separately by the producer. It includes any transport margins charged by the producer on the same invoice, even when they are included as a separate item on the invoice.

The difference between these two basic valuation concepts relates therefore to 'trade and transport margins' on the one hand, and to 'taxes less subsidies' on products on the other. Producer prices were the main valuation concept in the former system of national accounts. When we also introduce the concept of producer prices, the difference between these two valuation concepts can be attributed to the two factors.

- Producer prices is the amount receivable by the producer from the purchaser for a unit of a good or service produced as output minus any value added tax invoiced to the purchaser. It excludes any transport charges invoiced separately by the producer.

Thus, the relationship between the different types of prices can be shown as follows:

Purchaser price (excluding any deductible VAT)

- Non-deductible VAT

- Trade and transport margins

$=$ Producer price

- Taxes on products (excl. VAT)

+ Subsidies on products

$=$ Basic price

Producer prices do not include the cost of margins, since these are not part of the production process. These costs are paid by final users of commodities and are included in purchaser prices. Since a commodity is produced by several activities and the cost of margins is paid by consumers, margins are demanded by commodities, and they are reported as a part of the use table. 


\section{Appendix B Activities and Commodities in the I3E Model}

Table B.1: Activities

\begin{tabular}{|c|c|c|}
\hline Abbreviation & Name & NACE Codes \\
\hline ACC & Accommodation and hotel services & $55-56,79$ \\
\hline AGR & Agriculture & $1-3$ \\
\hline ATS & Air transportation & 51 \\
\hline BFM & Basic metal manufacturing & $24-25$ \\
\hline BPP & Basic pharmaceutical products & 21 \\
\hline CHE & Chemicals and chemical products & 20 \\
\hline $\mathrm{CON}$ & Construction & $41-43$ \\
\hline EDU & Education sector & 85 \\
\hline ELC & Electricity & \\
\hline FBT & Food, beverage and tobacco & $10-12$ \\
\hline FSR & Financial services & $64-66,77$ \\
\hline HHS & Health sector & $86-88$ \\
\hline HTP & High-technology products & $26-28$ \\
\hline LTS & Land transportation & 49 \\
\hline NGS & Natural gas supply & \\
\hline OIN & Other industrial products & $17,18,33$ \\
\hline OMN & Other mining products & \\
\hline ONM & Other non-metallic products & 23 \\
\hline OTM & Other manufacturing & $31-32$ \\
\hline PEA & Peat & \\
\hline PET & Petroleum & \\
\hline PUB & Public sector & 84 \\
\hline RES & Real estate services & 68 \\
\hline RUP & Rubber and plastic products & 22 \\
\hline SER & Other services & remaining* \\
\hline TEL & Telecommunication services & 61 \\
\hline TEX & Textile & $13-15$ \\
\hline TRD & Trade & $45-47$ \\
\hline TRE & Transportation equipment & $29-30$ \\
\hline WAT & Water and sewerage & $36,37-39$ \\
\hline WTS & Water transportation & 50 \\
\hline WWP & Wood and wood products & 16 \\
\hline
\end{tabular}


Table B.2: Commodities

\begin{tabular}{|c|c|c|c|}
\hline AGR & Agriculture & $\mathrm{BFM}$ & Basic metal manufacturing \\
\hline PEA & Peat & HTP & High-technology products \\
\hline $\mathrm{COA}$ & Coal & TRE & Transportation equipment \\
\hline $\mathrm{CRO}^{*}$ & Crude oil & ELC & Electricity \\
\hline $\mathrm{OMN}^{*}$ & Other mining products & NGS & Natural gas supply \\
\hline FBT & Food, beverage and tobacco & WAT & Water and sewerage \\
\hline TEX & Textile & $\mathrm{CON}$ & Construction \\
\hline WWP & Wood and wood products & TRD & Trade \\
\hline OIN & Other industrial products & LTS & Land transportation \\
\hline GAL & Gasoline & WTS & Water transportation \\
\hline KRS & Kerosene & ATS & Air transportation \\
\hline FUO* & Fuel oil & $\mathrm{ACC}$ & Accommodation and hotel services \\
\hline LPG & Liquid petroleum gas & TEL & Telecommunication services \\
\hline DIE & Diesel & FSR & Financial services \\
\hline OPP & Other petroleum products & RES & Real estate services \\
\hline OTM & Other manufacturing & PUB & Public services \\
\hline $\mathrm{CHE}$ & Chemicals and chemical products & EDU & Education sector \\
\hline BPP & Basic pharmaceutical products & HHS & Health sector \\
\hline RUP & Rubber and plastic products & SER & Other services \\
\hline ONM & Other non-metallic products & & \\
\hline
\end{tabular}

*: Not subject to private consumption. 


\section{Appendix C Mapping of HBS Consumption to the I3E Model}

\begin{tabular}{|c|c|c|}
\hline HBS & Definition & I3E \\
\hline H01_01_16 & Takeaway food brought/delivered to home & ACC \\
\hline H01_02 & Meals away from home (incl. take-out tea/coffee) & ACC \\
\hline H08_06_01 & Delivery charges (e.g. for takeaways) and other transport services & ACC \\
\hline H09_09_03 & Holidays in the ROI (accommodation) & ACC \\
\hline H09_09_04 & Holidays abroad (including accommodation) & $\mathrm{ACC}$ \\
\hline H09_09_01 & Package holidays in the ROI & $\mathrm{ACC}$ \\
\hline H09_09_02 & Package holidays abroad & ACC \\
\hline H09_09_05 & Money spent on holidays when abroad & ACC \\
\hline H09_19_02 & Catering services (e.g. for wedding) & ACC \\
\hline H09_19_04 & Room hire (e.g. function room) & ACC \\
\hline H01_01_10 & Total fish & AGR \\
\hline H01_01_11 & Fruit and nuts & AGR \\
\hline H01_01_12 & Vegetables & AGR \\
\hline H08_06_02 & Air travel within ROI & ATS \\
\hline H08_06_03 & International air travel & ATS \\
\hline H07_17 & Cutlery & BFM \\
\hline H07_18 & Kitchen utensils & BFM \\
\hline H07_20 & Small tools (e.g. hammer, spanner, saw) & BFM \\
\hline H06_08 & Hair products & $\mathrm{BPP}$ \\
\hline H06_09 & Cosmetics and related accessories & BPP \\
\hline H06_10 & Baby toiletries/accessories (e.g. nappies) & BPP \\
\hline H09_01_01 & Prescription medication & BPP \\
\hline H09_01_02 & Over the counter (OTC) medicines & BPP \\
\hline H09_01_03 & Other medical products (plasters, bandages, etc.) & BPP \\
\hline H09_01_10 & Spectacles and lenses (including accessories and repairs) & BPP \\
\hline H09_13 & Plants, flowers, seeds, fertilisers and insecticides & $\mathrm{BPP}$ \\
\hline H06_01 & Detergents, washing up liquid and washing powder & $\mathrm{CHE}$ \\
\hline H06_02 & Disinfectants, polishes and other cleaning materials & $\mathrm{CHE}$ \\
\hline H06_03 & Non-durable small household articles & CHE \\
\hline H06_04 & Toilet paper & $\mathrm{CHE}$ \\
\hline H06_05 & Toiletries - disposable (e.g. toothpaste) & $\mathrm{CHE}$ \\
\hline H06_06 & Toilet soap, liquid soap, shower gel, etc. & $\mathrm{CHE}$ \\
\hline H06_07 & Toilet requisites (e.g. toothbrush and comb) & $\mathrm{CHE}$ \\
\hline H05_15 & Other materials for the maintenance and repair of the dwelling & $\mathrm{CON}$ \\
\hline
\end{tabular}




\begin{tabular}{|c|c|c|}
\hline H05_17 & Services for maint. and repair of the dwelling (e.g. electrician, painter) & $\mathrm{CON}$ \\
\hline H05_19 & Capital improvements contractor (e.g. extension and room conversion) & $\mathrm{CON}$ \\
\hline H08_02_02 & Diesel & DIE \\
\hline H09_07 & Education and training & EDU \\
\hline H04_01 & Electricity & ELC \\
\hline H01_01_01 & Bread & FBT \\
\hline H01_01_02 & Flour & FBT \\
\hline H01_01_03 & Pastries and biscuits & FBT \\
\hline H01_01_04 & Breakfast cereals & FBT \\
\hline H01_01_05 & Milk, cream yoghurt and cheese & FBT \\
\hline H01_01_06 & Butter, fats and cooking oil & FBT \\
\hline H01_01_07 & Eggs & FBT \\
\hline H01_01_08 & Pasta, pizza, quiche and grains & FBT \\
\hline H01_01_09 & Meat & FBT \\
\hline H01_01_13 & Sugars, confectionery and snacks & FBT \\
\hline H01_01_14 & Other food items & FBT \\
\hline H01_01_15 & Non-alcoholic beverages & FBT \\
\hline $\mathrm{H} 02$ & Total drink and tobacco & FBT \\
\hline H09_12_07 & Bank service charges & FSR \\
\hline H09_12_08 & Bank and Post Office counter charges & FSR \\
\hline H09_12_09 & Fees and service charges of brokers/investment consultants & FSR \\
\hline H08_03_01 & Vehicle insurance & FSR \\
\hline H08_03_02 & Travel insurance & FSR \\
\hline H09_10 & Insurance/pension premiums & FSR \\
\hline H05_06 & Second dwelling - mortgage and home insurance & FSR \\
\hline H05_08 & Primary dwelling insurance & FSR \\
\hline H08_02_01 & Petrol & GAL \\
\hline H09_01_04 & Doctor (not consultant) & HHS \\
\hline H09_01_05 & Dentist & HHS \\
\hline H09_01_06 & Specialist practice (including consultant, orthodontist) & HHS \\
\hline H09_01_07 & Physiotherapy and other paramedical services/fees & HHS \\
\hline H09_01_08 & Services of medical analysis labs & HHS \\
\hline H09_01_09 & Hospital services & HHS \\
\hline H09_18_05 & Charitable donations and subscriptions & HHS \\
\hline H09_19_01 & Present - not specified & HHS \\
\hline H07_23 & Audio equipment & HTP \\
\hline H07_24 & Accessories for audio equipment & HTP \\
\hline
\end{tabular}


H07_25 Television sets $\quad$ HTP

H07_26 DVD and digital media players $\quad$ HTP

H07_27 Satellite dish purchase $\quad$ HTP

H07_28 TV/video/audio/computer - spare parts $\quad$ HTP

H07_29 Cameras, camcorders and accessories $\quad$ HTP

H07_30 Optical instruments (e.g. binoculars) HTP

H07_31 Computers (including media tablets, laptops) HTP

H07_32 Printers, ink cartridges, calculators and computer accessories $\quad$ HTP

H07_33 Consoles for computer games $\quad$ HTP

H07_36 DVD and CD (pre recorded and blank) HTP

H07_37 Film/memory card, hard drives and memory sticks $\quad$ HTP

H07_40 Major durables for indoor recreation $\quad$ HTP

H09_02_01 Telephone, answering and fax machine - purchase and repair HTP

H09_02_02 Mobile phone/car phone purchase HTP

H07_05 Fridges and freezers $\quad$ HTP

H07_06 Washing machines, spin and tumble dryers HTP

H07_07 Dishwasher HTP

H07_08 Gas cooker HTP

H07_09 Electric cooker and combined electric/gas (including microwave) HTP

H07_10 Other major household appliances (including rental) HTP

H07_11 Heaters/air conditioners/shower units etc. HTP

H07_12 Cleaning equipment (e.g. vacuum) HTP

H07_13 Small electric household appliances $\quad$ HTP

H07_14 Gas/electric appliances spare parts $\quad$ HTP

H07_19 Electrical tools for house and garden $\quad$ HTP

H07_21 Electrical consumables (e.g. batteries, bulbs) HTP

H07_22 Lighting equipment HTP

H07_45 Electrical items for personal care (e.g. hair dryer) HTP

H07_39 Musical instruments (purchase and hire) HTP

H07_44 Lawn mowers $\quad$ HTP

H09_01_11 Therapeutic equipment - non optical items (e.g. wheelchair) HTP

H09_08_02 Equipment for sport, camping and open-air recreation (purc., rep., hire) HTP

H09_08_03 Other items for games and sports $\quad$ HTP

H09_15_01 Jewellery, clocks and watches $\quad$ HTP

\begin{tabular}{lll} 
H09_16 & Baby equipment & HTP \\
\hline H04_03 & Liquid Fuels (e.g. heating oil) & KRS \\
\hline H08_05 & Bus, Luas, rail and taxi & LTS
\end{tabular}




\begin{tabular}{|c|c|c|}
\hline H08_06_04 & Other purchased transport services & LTS \\
\hline H04_02 & Gas & NGS \\
\hline H05_18 & Central heating installation & OIN \\
\hline H09_06 & Reading materials & OIN \\
\hline H07_16 & Glassware, china and pottery & ONM \\
\hline H07_46 & Fancy and decorative goods (e.g. mirrors) & ONM \\
\hline H08_02_03 & Other fuels and lubricants for personal transport & OPP \\
\hline H05_23 & Carpets and rugs & OTM \\
\hline H07_01 & Household furniture & OTM \\
\hline H07_42 & Garden furniture & OTM \\
\hline H04_04 & Solid Fuels & PEA \\
\hline H09_12_10 & Passport fees & PUB \\
\hline H09_12_11 & Birth/death/marriage certificate fees & PUB \\
\hline H05_12 & Other services relating to dwelling & RES \\
\hline H09_12_04 & Conveyancing, estate agents and surveyors & RES \\
\hline H05_04 & Mortgage payment (primary dwelling) & RES \\
\hline H05_05 & Purchase (including deposit) on primary dwelling & RES \\
\hline H05_07 & Purchase (including deposit) on second dwelling & RES \\
\hline H05_01 & Rent paid for primary dwelling & RES \\
\hline H05_02 & Ground rent and other rentals paid by tenants & RES \\
\hline H05_03 & Second dwelling rent & RES \\
\hline H05_24 & Hard floor coverings & RUP \\
\hline H05_14 & Equipment hire and small material purchase (e.g. sandpaper) & RUP \\
\hline H05_20 & Double glazing, kitchen units, sheds, etc. & RUP \\
\hline H05_21 & Purchase of materials for capital improvements & RUP \\
\hline H05_22 & Bathroom fittings & RUP \\
\hline H05_16 & Central heating maintenance & SER \\
\hline H09_19_05 & Postage (e.g. stamps and registered mail) & SER \\
\hline H09_12_03 & Trade union and professional organisation contributions & SER \\
\hline H09_11 & Pet costs & SER \\
\hline H09_19_06 & Photographic services & SER \\
\hline H09_19_10 & Other services (e.g. photocopying and newspaper advert) & SER \\
\hline H07_34 & Computer games/software & SER \\
\hline H07_35 & Downloads, streaming, apps and other internet services n.e.c & SER \\
\hline H07_43 & Garden accessories & SER \\
\hline H09_03 & Internet, telephone and television subscriptions & SER \\
\hline H09_04 & Admission and subscription charges - sports and leisure & SER \\
\hline
\end{tabular}


H09_05 Betting and lotteries $\quad$ SER

H09_08_01 Games and toys $\quad$ SER

H09_19_11 Celebration articles $\quad$ SER

H07_02 Furniture recovering and repairs $\quad$ SER

H07_15 Repairs and insurance for household appliances $\quad$ SER

H07_38 Repairs and/or insurance of TV, video, audio, DVD and computer SER

H07_41 Repair and maintenance of other major durables for recreation SER

H09_19_07 Cleaning of clothing $\quad$ SER

H09_19_08 Cleaning of clothing $\quad$ SER

H09_19_09 Footwear repair and hire $\quad$ SER

H09_12_01 Legal fees paid to solicitors $\quad$ SER

H09_12_12 Other licences $\quad$ SER

H09_14 Hairdressing and personal grooming SER

H09_15_03 Repair to personal goods $\quad$ SER

H09_15_04 Personal goods not otherwise specified $\quad$ SER

H09_17 Care, domestic and household services $\quad$ SER

H09_19_03 Funeral expenses $\quad$ SER

H09_02_03 Telephone account payment $\quad$ TEL

H09_02_04 Mobile phone account payments TEL

H09_02_05 Mobile phone top-up and other payments $\quad$ TEL

H03 Total clothing and footwear $\quad$ TEX

H07_03 Bedroom textiles

H07_04 Other household textiles $\quad$ TEX

H09_15_02 Leather and travel goods $\quad$ TEX

\begin{tabular}{llc}
\hline H08_04 & Vehicle maintenance and other costs & TRD \\
\hline H08_01_01 & Motor cars - new & TRE \\
H08_01_02 & Motor cars - second hand & TRE \\
H08_01_03 & Motor cycles & TRE \\
H08_01_04 & Bicycles purchase & TRE \\
H08_01_05 & Other vehicles & TRE \\
\hline H05_10 & Water charges & WAT \\
H05_11 & Refuse/sewage collection and skip hire & WAT \\
\hline H05_13 & Paint, wallpaper, timber and plaster & WWP \\
\hline
\end{tabular}




\section{References}

CSO. (2017). National Income and Expenditure 2017 Frequently Asked Questions (Information Note). Central Statistical Office (CSO). https://www.cso.ie/en/methods/nationalaccounts/din/ nie2017faq/.

EUROSTAT. (1995). European System of Accounts (ESA 1995).

EUROSTAT. (2008). Eurostat Manual of Supply, Use and Input-Output Tables.

EUROSTAT. (2013). European System of Accounts (ESA 2010).

Pyatt, G. (1988). A sam approach to modeling. Journal of Policy Modeling, 10(3), 327-352.

Round, J. (2003). Social Accounting Matrices and SAM-based Multiplier Analysis. In F. Bourguignon \& L. A. Pereira da Silva (Eds.), The Impact of Economic Policies on Poverty and Income Distribution: Evaluation Techniques and Tools (chap. 14). The World Bank, Washington, DC.

UN. (1999). Handbook of Input-Output Table Compilation and Analysis. 
Whitaker Square,

Sir John Rogerson's Quay,

Dublin 2

Telephone +35318632000

Email admin@esri.ie

Web www.esri.ie

Twitter @ESRIDublin

ISBN 978-0-7070-0503-4 